\title{
Pengaruh Kompensasi dan Komitmen Organisasi Melalui Motivasi Kerja Terhadap Kinerja Karyawan PT Penta Valent Jambi
}

\author{
${ }^{1}$ M. Iman Khoeruman, ${ }^{2}$ Sayid Syekh, ${ }^{3}$ Susilawati \\ ${ }^{1}$ Mahasiswa Magister Manajemen Universitas Batanghari, \\ ${ }^{2}$ Dosen Magister Manajemen Universitas Batanghari, \\ ${ }^{3}$ Dosen Magister Manajemen Universitas Batanghari
}

\begin{abstract}
This research aims to know the influence of organizational commitment Through compensation and Motivation of work on performance of employees of PT Penta Valent-Jambi. The diginakan method in the research of using path analysis (path analysis). Results of the study prove that compensation and organizational commitment to simultaneously effect positively and significantly to the motivation of working employees at PT Penta Valent-Jambi. Where the total direct and indirect influence of the compensation and the commitment of the Organization together against the motivation of 52.4\%, where the figure explains that directly compensation and organizational commitment to contribute against the work motivation of $52.4 \%$, while the rest of $47.6 \%$ is affected by other variables that are not included in this model.
\end{abstract}

Keywords: compensation, commitment, motivation, employee performance

\section{Pendahuluan}

Sumber daya manusia memiliki peranan sangat penting dalam berbagai sektor, karena sumber daya manusia merupakan faktor kunci untuk menggerakkan sumber daya yang lain yang ada dalam perusahaan ataupun instansi pemerintahan. Begitu pentingnya peranan sumber daya manusia mengakibatkan suatu organisasi harus mengalokasikan sejumlah dana yang cukup besar untuk peningkatan sumber daya manusia tersebut. Keberhasilan suatu organisasi dalam mencapai tujuannya juga tergantung faktor sumber daya manusia, dimana dibutuhkan suatu interaksi dan koordinasi yang didesain untuk menghubungkan tugas-tugas, baik perseorangan maupun kelompok dalam rangka mencapai tujuan organisasi. Sumber daya manusia merupakan faktor kunci untuk meningkatkan kinerja suatu organisasi (Hasibuan, 2010:63). Untuk mewujudkan tujuan yang diinginkan tersebut, maka salah satu cara yang harus ditempuh adalah dengan meningkatkan kinerja sumber daya manusia.

PT. Penta Valent Jambi yang merupakan salah satu perusahaan yang bergerak dibidang distributor obat dan alat-alat kesehatan, tentu tidak lepas pula dari permasalahan kinerja karyawannya. Kinerja karyawan menunjuk kepada kemampuan karyawan dalam melaksanakan keseluruhan tugas-tugas yang menjadi tanggung jawabnya. Tugas-tugas tersebut biasanya berdasarkan indikator-indikator keberhasilan yang telah ditetapkan. Pengertian tersebut menjelaskan bahwa kinerja dapat dimaknai sebagai keseluruhan unjuk kerja dari seorang karyawan.

Setiap organisasi baik swasta maupun organisasi pemerintahan berusaha untuk selalu meningkatkan kinerja pegawainya demi tercapai tujuan yang telah ditetapkan suatu organisasi tersebut. Karena kinerja karyawan memiliki peranan penting bagi organisasi, apabila kinerja yang ditampilkan rendah maka akan mengakibatkan organisasi dalam mencapai tujuan menjadi terhambat (Suwardi 
dan Utomo, J, 2011). Kinerja merupakan hasil kerja secara kualitas dan kuantitas yang dicapai oleh seorang pegawai dalam melaksanakan tugasnya sesuai dengan tanggung jawab yang diberikan kepadanya (Mangkunegara, 2010:9).

Namun beberapa tahun belakang ini kinerja yang diberikan oleh karyawan PT. Penta Valent Jambi cenderung kurang memuaskan bagi perusahaan, hal ini tampak dari nilai penjualan perusahaan yang cenderung berfluktuatif dan tidak mencapai target yang diinginkan. Seperti yang terlihat pada tabel penjualan berikut ini.

Tabel. 1

Target Penjualan PT. Penta Valent Jambi Periode 2013 s.d 2016.

\begin{tabular}{|c|c|c|c|c|c|c|c|}
\hline \multirow{2}{*}{ No } & \multirow{2}{*}{ Tahun } & \multicolumn{6}{|c|}{ Realisasi Penjualan Produk } \\
\cline { 3 - 8 } & & \multicolumn{3}{|c|}{ Obat-obatan } & \multicolumn{3}{c|}{ Alat Kesehatan } \\
\cline { 3 - 8 } & Target (Rp) & Realisasi (Rp) & $\%$ & Target (Rp) & Realisasi (Rp) & $\%$ \\
\hline 1 & 2013 & $1,539,462,500$ & $1,303,308,953$ & $84.66 \%$ & $1,012,633,000$ & $874,307,332$ & $86.34 \%$ \\
\hline 2 & 2014 & $1,570,073,000$ & $1,346,180,590$ & $85.74 \%$ & $1,204,375,000$ & $1,058,043,438$ & $87.85 \%$ \\
\hline 3 & 2015 & $1,625,025,000$ & $1,421,246,865$ & $87.46 \%$ & $1,246,528,000$ & $1,074,008,525$ & $86.16 \%$ \\
\hline 4 & 2016 & $1,673,776,000$ & $1,392,246,877$ & $83.18 \%$ & $1,283,923,000$ & $1,073,616,413$ & $83.62 \%$ \\
\hline
\end{tabular}

Sumber: PT. Penta Valent Jambi (2016)

Tabel 1 diatas dapat dilihat bahwasanya penjualan produk PT. Penta Valent Jambi kurun waktu empat tahun belakang ini cenderung berfluktuatif, dimana tiap tahunnya dapat dilihat penjualan perusahaanpun tidak pernah mencapai target 100 persen. Dimana untuk penjualan produk obat-obatan, tampak bahwasanya dari tahun 2013 s.d 2015 mengalami peningkatan, kemudian turun kembali pada tahun 2016 hingga mencapai 83,18\% realisasinya. Begitu pula untuk penjualan alat kesehatan, untuk tahun 2014 mengalami peningkatan dari tahun sebelumnya, kemudian terus turun hingga tahun 2016 mencapai $83,62 \%$ realisasinya. Berdasarkan pengamatan yang penulis lakukan pada PT. Penta Valent Jambi tidak teralisasinya $100 \%$ penjualan produk dikarenakan kurangnya gairah kerja karyawan dalam beberapa waktu belakangan ini.

Berdasarkan hasil penelitian McClelland (1961), Edward Murray (1957), Miller dan Gordon W (1970), Mangkunegara (2000) menyimpulkan bahwa adanya hubungan yang positif antara motivasi dengan pencapaian kinerja. Artinya, pimpinan, manajer dan pegawai yang mempunyai motivasi yang tinggi akan dapat mencapai kinerja yang tinggi pula, dan sebaliknya mereka yang kinerjanya rendah disebabkan karena motivasi kerjanya rendah (Mangkunegara, 2014:76).

Beberapa hasil penelitian juga telah membuktikan bahwasanya motivasi dapat mempengaruhi kinerja pegawai, seperti penelitian yang dilakukan oleh Dermawan, Sudibya dan Utama (2012), Supriyani dan Mahmud (2013), Suwardi dan Utomo (2011) dan Abrivianto, Swasto dan Utami (2014) yang mengungkapkan bahwasanya kinerja pegawai juga dipengaruhi oleh motivasi. Motivasi adalah suatu faktor yang mendorong seseorang untuk melakukan suatu aktivitas tertentu, oleh karena itu motivasi sering kali diartikan pula sebagai faktor pendorong perilaku seseorang (Sutrisno, 2010). 
Namun berdasarkan hasil pengamatan pada PT. Penta Valent Jambi masih adanya beberapa karyawan yang kurang memiliki dorongan yang kuat dari dalam dirinya untuk dapat bekerja secara maksimal, seperti masih kurangnya inisiatif pegawai dalam melaksanakan pekerjaannya, hal ini terlihat bahwa tugas yang dilakukan hanya terfokus berdasarkan perintah atasan, bukan atas dasar inisiatif sendiri untuk melaksanakan pekerjaan. Berdasarkan hasil observasi yang penulis lakukan hal ini ternyata berkaitan dengan pemberian insentif karyawan yang dirasa belum begitu adil diberikan kepada karyawan. Pada tabel berikut dapat dilihat besaran insentif yang diterima oleh karyawan pertahun periode 2013 s.d 2016.

\section{Tabel 2}

Besaran Insentif Karyawan PT. Penta Valent Jambi Periode 2013 s.d 2016.

\begin{tabular}{|c|l|c|c|c|c|}
\hline \multirow{2}{*}{ No } & \multirow{2}{*}{ Jabatan } & & \multicolumn{3}{|c|}{ Insentif Karyawan } \\
\cline { 3 - 6 } & & $\mathbf{2 0 1 3}(\mathbf{R p})$ & $\mathbf{2 0 1 4}(\mathbf{R p})$ & $\mathbf{2 0 1 5}(\mathbf{R p})$ & $\mathbf{2 0 1 6}(\mathbf{R p )}$ \\
\hline $\mathbf{1}$ & \multicolumn{1}{|c}{} & $\mathbf{3}$ & $\mathbf{4}$ & $\mathbf{5}$ & $\mathbf{6}$ \\
\hline 1 & Kepala Cabang & $5,000,000$ & $5,500,000$ & $4,000,000$ & $4,300,000$ \\
\hline 2 & Supervisor & $2,700,000$ & $3,000,000$ & $2,500,000$ & $2,400,000$ \\
\hline 3 & Salesman & $4,500,000$ & $5,000,000$ & $3,700,000$ & $3,900,000$ \\
\hline 4 & Admin & - & - & - & - \\
\hline 5 & Apoteker & $1,700,000$ & $2,000,000$ & $1,600,000$ & $1,800,000$ \\
\hline 6 & Pengantar Barang & - & - & - & - \\
\hline 7 & Bagian Gudang & - & - & - & - \\
\hline
\end{tabular}

Sumber: PT. Penta Valent Jambi (2016)

Tabel 2 diatas dapat dilihat bahwasanya tidak semua karyawan memperoleh insentif dari perusahaan. Hanya untuk kepala cabang, supervisor, salesman dan apoteker saja. Sedangkan untuk admin, pengantar barang dan bagian gudang tidak mendapatkan insentif dari perusahaan. Hal ini tentu saja membuat kecemburuan sosial dalam lingkungan perusahaan bagi mereka yang tidak mendapatkan insentif. Karena seharusnya semua karyawan berhak untuk mendapatkan insentif dari perusahaan, karena pada dasarnya semua karyawan sama-sama memberikan kontribusi untuk kemajuan perusahaan.

Penelitian juga telah membuktikan jika kompensasi memiliki pengaruh terhadap motivasi kerja, diantaranya yaitu penelitian yang dilakukan oleh Wulansari, P., Damanik, H.I., dan Prasetio, A.P (2014), Laminingrum, A.K (2016) dan Verizqy, T dan Kusumastuti, R (2014) yang menyatakan bahwa kompensasi memiliki pengaruh yang positif dan signifikan terhadap motivasi kerja.

Selain berpengaruh terhadap motivasi kerja, kompensasi juga memiliki pengaruh terhadap kinerja hal ini dikemukakan oleh beberapa penelitian yang telah dilakukan sebelumnya yakni diantaranya penelitian yang dilakukan oleh Hakim dan Widyatmini (2008), Dermawan, Sudibya dan Utama (2012) dan Sarah Sasmita (2009) yang menyatakan bahwa kompensasi memiliki pengaruh yang positif dan signifikan terhadap kinerja.

Besarnya kompensasi mencerminkan status, pengakuan dan tingkat pemenuhan kebutuhan yang dinikmati oleh karyawan beserta keluarganya. Jika balas jasa yang diterima karyawan semakin besar berarti jabatannya semakin tinggi, statusnya semakin baik, dan pemenuhan kebutuhannya yang dinikmatinya 
semakin banyak pula. Pada tabel 1.3 berikut ini dapat dilihat besaran kompensasi berupa gaji yang diterima oleh karyawan PT. Penta Valent Jambi Periode 2013 s.d 2016.

Tabel 3

Kompensasi Karyawan PT. Penta Valent Jambi Periode 2013 s.d 2016.

\begin{tabular}{|c|c|c|c|c|c|}
\hline \multirow{2}{*}{ No } & \multirow{2}{*}{ Jabatan } & \multicolumn{4}{|c|}{ Gaji Karyawan } \\
\hline & & $2013(\mathrm{Rp})$ & $2014(\mathrm{Rp})$ & $2015(R p)$ & $2016(\mathrm{Rp})$ \\
\hline 1 & 2 & 3 & 4 & 5 & 6 \\
\hline 1 & Kepala Cabang & 8.000 .000 & 9.000 .000 & 9.000 .000 & 9.000 .000 \\
\hline 2 & Supervisor & 3.500 .000 & 4.000 .000 & 4.000 .000 & 4.000 .000 \\
\hline 3 & Salesman & 2.300 .000 & 2.500 .000 & 2.500 .000 & 2.500 .000 \\
\hline 4 & Admin & 3.200 .000 & 3.500 .000 & 3.500 .000 & 3.500 .000 \\
\hline 5 & Apoteker & 3.500 .000 & 4.000 .000 & 4.000 .000 & 4.000 .000 \\
\hline 6 & Pengantar Barang & 2.700 .000 & 3.000 .000 & 3.000 .000 & 3.000 .000 \\
\hline 7 & Bagian Gudang & 2.700 .000 & 3.000 .000 & 3.000 .000 & 3.000 .000 \\
\hline
\end{tabular}

Sumber: PT. Penta Valent Jambi (2016)

Tabel 3 diatas dapat dilihat bahwasanya besaran gaji yang diterima oleh karyawan, mulai dari kepala cabang sampai dengan bagian gudang. Bila dilihat dari besaran gaji yang diterima oleh karyawan, sebenarnya gaji diterima sudah cukup besar, diatas dari Upah Minimum Provinsi Jambi per 1 Januari 2016 oleh pemerintah dengan jumlah Rp.1.906.650,-. Penetapan itu berdasarkan kebutuhan hidup layak dan dengan memperhatikan produktivitas dan pertumbuhan ekonomi.

Namun yang menjadi permasalahan disini berdasarkan pengamatan yang penulis lakukan kurang optimalnya kinerja karyawan ini karena tidak adanya standar gaji, dan adanya kecemburuan sosial karyawan baru masuk biasanya bawaan dari atasan, dengan posisi sama atau lebih rendah dari karyawan lama, gajinya lebih tinggi, sehingga menyebabkan menurun kinerja karyawan lama yang merasa dirugikan.

Kompensasi menurut Wibowo (2010:176) merupakan kontra prestasi terhadap penggunaan tenaga atau balas jasa yang telah diberikan oleh tenaga kerja. Kompensasi adalah imbalan yang pantas atas jasa yang telah mereka berikan kepada perusahaan, karena kompensasi baik dalam bentuk gaji, insentif, dan penghargaan adalah sarana untuk memenuhi kebutuhan. Kompensasi yang mereka terima mencerminkan ukuran dari apa yang telah mereka lakukan atau berikan kepada perusahaan, sehingga hal ini berhubungan dengan loyalitas dan nilai karya dan prestasi bagi perusahaan.

Kompensasi adalah penghargaan atau ganjaran pada para pekerja yang telah memberikan kontribusi dalam mewujudkan tujuannya, melalui kegiatan yang disebut bekerja (Nawawi, 2006:105). Kompensasi juga merupakan penghargaan yang diberikan karyawan baik langsung maupun tidak langsung, financial maupun non financial yang adil kepada karyawan atas sumbangan mereka dalam mencapai tujuan organisasi, sehingga pemberian kompensasi sangat dibutuhkan oleh perusahaan manapun guna meningkatkan kinerja karyawannya. Adapun bentuk kompensasi finansial adalah gaji, tunjangan, bonus, dan komisi, sedangkan untuk kompensasi non-finansial diantaranya pelatihan, wewenang dan tanggung jawab, penghargaan atas kinerja serta lingkungan kerja yang mendukung. 
Begitu juga komitmen organisasi, hal tersebut memiliki pengaruh terhadap motivasi kerja, diantaranya yaitu penelitian yang dilakukan oleh Farida, S.I., Iqbal, M., dan Kurniasih, A (2016), Tranggono, R.P., dan Kartika, A (2008), dan Arifah, D.A., dan Romadhon, C (2015) yang menyatakan bahwa komitmen organisasi memiliki pengaruh yang positif dan signifikan terhadap motivasi kerja.

Selain berpengaruh terhadap motivasi kerja, komitmen organisasi juga memiliki pengaruh terhadap kinerja hal ini dikemukakan oleh beberapa penelitian yang telah dilakukan sebelumnya yakni diantaranya penelitian yang dilakukan oleh Supriyani dan Mahmud (2013), Abrivianto, Swasto dan Utami (2014) dan Suwardi dan Utomo (2011) yang menyatakan secara signifikan dan positif kinerja dipengaruhi oleh komitmen organisasi. Artinya apabila pegawai memiliki komitmen yang tinggi terhadap organisasi tempat mereka bernaung, maka dengan senantiasa pegawai tersebut akan mampu memberikan hasil kerja yang optimal. Allen dan Mayer dalam Sanusi (2012) menjelaskan bahwasanya komitmen organisasi merupakan suatu keadaan psikologi dengan karakteristik sebagai berikut: 1) meyakini dan menerima tujuan yang dimiliki oleh organisasi; 2) kesediaan untuk berusaha dengan sungguh-sungguh demi organisasi; 3) mempunyai keinginan yang kuat untuk tetap menjadi anggota organisasi.

Selain itu pula Luthans dalam Supriyani dan Mahmud (2013) yang mengungkapkan bahwa komitmen organisasi sebagai sebuah sikap yang merefleksikan loyalitas pegawai kepada organisasi dan merupakan suatu proses berkelanjutan dimana anggota organisasi mengungkapkan perhatian mereka terhadap organisasi, terhadap keberhasilan organisasi serta kemajuan yang berkelanjutan.

Adapun salah satu indikasi karyawan yang memiliki komitmen yang tinggi terhadap organisasi salah satunya yaitu dapat dilihat dari faktor kehadirannya. Faktor kehadiran sangat penting karena dapat menjadi gambaran seberapa jauh karyawan menyadari bahwa kehadiran mereka di dalam organisasi menjadi sangat penting. Begitu juga dengan PT. Penta Valent Jambi, kehadiran karyawan dapat menjadi gambaran seberapa jauh dukungan karyawan terhadap pencapaian targettarget pekerjaan terealisasi. Pada tabel berikut dapat dilihat hasil rekapitulasi kehadiran karyawan periode 2013-2016 yang disajikan pada Tabel 1.3 berikut.

\section{Tabel 4.}

Rekapitulasi Kehadiran Karyawan PT. Penta Valent Jambi Periode 2013 s.d 2016.

\begin{tabular}{|c|c|c|c|c|c|c|c|c|c|}
\hline \multirow{2}{*}{ Tahun } & \multirow{2}{*}{$\begin{array}{l}\text { Jumlah } \\
\text { Pegawai }\end{array}$} & \multirow{2}{*}{$\begin{array}{c}\text { Jumlah } \\
\text { Hari Wajib }\end{array}$} & \multirow{2}{*}{$\begin{array}{c}\text { Jumlah } \\
\text { Hari Hadir }\end{array}$} & \multicolumn{4}{|c|}{ Keterangan } & \multirow{2}{*}{$\begin{array}{l}\text { Akumulasi } \\
\text { Kehadiran }\end{array}$} & \multirow{2}{*}{$\begin{array}{c}\% \\
\text { Kehadiran }\end{array}$} \\
\hline & & & & Izin & Alpa & Sakit & Cuti & & \\
\hline 1 & 2 & 3 & 4 & 5 & 6 & 7 & 8 & 9 & 10 \\
\hline 2013 & 40 & 243 & 9720 & 121 & 23 & 81 & 182 & 9313 & $95.81 \%$ \\
\hline 2014 & 42 & 243 & 6 & 1 & 25 & 89 & 185 & 9790 & $95.92 \%$ \\
\hline 2015 & 43 & 243 & 1 & 11 & 3. & 87 & 17 & 10034 & $96.03 \%$ \\
\hline 2016 & 43 & 243 & 10449 & 125 & 29 & 93 & 197 & 10005 & $95.75 \%$ \\
\hline
\end{tabular}

Sumber: PT. Penta Valent Jambi (2016)

Tabel 4 di atas menunjukkan hasil rekapitulasi kehadiran pegawai selama 4 tahun priode tahun 2013-2016. Dari data yang diperoleh tampak bahwasanya tingkat ketidak hadiran karyawan dari absensi belum mencapai target sasaran yaitu 98\%. Dimana dari tahun 2013 hingga tahun 2016 persentase kehadiran yang paling tinggi berada pada tahun 2015 yaitu 96,03\%. Dari 4 indikator absensi cuti karyawan terbanyak pada tahun 2016 sebanyak 197 orang. Karyawan yang tidak 
masuk kerja dengan tanpa alasan tertinggi berada pada tahun 2015 yaitu sebanyak 31 orang. Tinggi tingkat ketidakhadiran karyawan merupakan salah satu indikasi jika karyawan sebenarnya belumlah begitu komit dengan organisasinya. Tingginya absensi karyawan memberikan gambaran bahwa sejauh ini karaywan belumlah memberikan dukungan yang penuh pada perusahaan terhadap pencapaian target-target perusahaan.

\section{Metode}

Penelitian ini yang menjadi objek penelitian adalah PT. Pentavalent Jambi. Dimana jumlah populasi dalam penelitian sebanyak 43 orang karyawan. Penelitian ini lebih diarahkan pada proses analisis pengaruh antara kompensasi dan komitmen organisasi melalui motivasi kerja terhadap kinerja karyawan pada PT. Pentavalent Jambi. Dalam penelitian ini variabel bebasnya adalah kompensasi $\left(\mathrm{X}_{1}\right)$ dan komitmen organisasi $\left(\mathrm{X}_{2}\right)$, sedangkan variabel interveningnya adalah motivasi kerja (Y) dan variabel terikatnya adalah kinerja (Z) pegawai pada PT. Pentavalent Jambi.

\section{Uji Hipotesis}

Koefisien Determinasi $\left(\boldsymbol{R}^{2}\right)$

Koefisien determinasi (KD) pada intinya mengukur seberapa jauh kemampuan model dalam menerangkan variasi variabel terikat. Nilai koefisien determinasi adalah dari nol (0) dan satu (1), nilai $\mathrm{r}^{2}$ yang kecil berarti kemampuan variabel-variabel independent dalam menjelaskan variasi variabel dependent amat terbatas. Nilai yang mendekati satu berarti variabel-variabel independent memberikan hampir semua informasi yang dibutuhkan untuk memprediksikan variasi variabel dependent. Analisis Koefisien determinasi (KD) digunakan untuk melihat seberapa besar variabel independent $(\mathrm{X})$ berpengaruh terhadap variabel dependent $(\mathrm{Y})$ yang dinyatakan dalam persentase.

Untuk mencari besarnya pengaruh yang ditimbulkan oleh variabel bebas terhadap bariabel tak bebas digunakan koefisien determinan dengan rumus: $\mathrm{KD}=$ $\mathrm{R}^{2} \times 100 \%$

Dimana: $\mathrm{KD}=$ Koefisien Determinasi (Seberapa jauh perubahan variabel $\mathrm{Y}$ dipergunakan oleh variabel $\mathrm{X} ; \mathrm{R}=$ Koefisien Korelasi

\section{Uji t (Parsial)}

Uji parsial (Uji t) untuk menjawab hipotesis dua, tiga, lima, enam dan delapan. Uji ini digunakan untuk mengetahui pengaruh variabel bebas (independent variable) terhadap variabel terikat (dependent variable) secara parsial. Pengujian ini dilakukan dengan membandingkan $t_{\text {hitung }}$ dengan $t_{\text {tabel }}$ pada derajat kesalahan 5\%. Apabila nilai $t_{\text {hitung }}>t_{\text {tabel }}$, maka variabel bebasnya (independent variable) memberi pengaruh yang signifikan terhadap variabel terikat (Y). Sebaliknya Apabila nilai $t_{\text {hitung }}<t_{\text {tabel, }}$, maka variabel bebasnya $(\mathrm{X})$ tidak memberi pengaruh yang signifikan terhadap variabel terikat (Y). Kriteria dari pengujian hipotesis secara parsial pada tingkat signifikansi 0,05 (5\%) adalah sebagai berikut:

1. Apabila $t_{\text {hitung }}>t_{\text {tabel }}$ atau alpha $<0.05$, maka tolak $\mathrm{H}_{0}$ dan terima $\mathrm{H}_{1}$

2. Apabila $\mathrm{t}_{\text {hitung }}<\mathrm{t}_{\text {tabel }}$ atau alpha $>0.05$, maka terima $\mathrm{H}_{0}$ dan tolak $\mathrm{H}_{1}$ 


\section{Uji F (Simultan)}

Uji $\mathrm{F}$ dapat juga dilakukan dengan melihat nilai probabilitas alphanya, apabila alpha $<0.05$ berarti beberapa variabel bebas $\left(\mathrm{X}_{1}, \mathrm{X}_{2}\right)$ memberikan pengaruh signifikan terhadap variabel terikatnya (Y). Sebaliknya apabila apabila alpha $>0.05$ berarti beberapa variabel bebas tidak memberikan pengaruh yang signifikan terhadap variabel terikatnya.

Kriteria pengujian hipotesis secara simultan pada tingkat signifikansi 0,05 (5\%) adalah sebagai berikut:

1. Apabila $F_{\text {hitung }}>\mathrm{F}_{\text {tabel }}$ atau alpha $<0.05$, maka tolak $\mathrm{H}_{0}$ dan terima $\mathrm{H}_{1}$

2. Apabila $F_{\text {hitung }}<\mathrm{F}_{\text {tabel }}$ atau alpha $>0.05$, maka terima $\mathrm{H}_{0}$ dan tolak $\mathrm{H}_{1}$

\section{Rancangan Uji Hipotesis}

Dari delapan hipotesis dapat dirancang uji hipotesis sebagai berikut:

1. Kompensasi, komitmen organisasi, motivasi dan kinerja karyawan pada PT. Pentavalent Jambi telah berlangsung dengan baik.

$\mathrm{H}_{0}$ : Kompensasi, komitmen organisasi, motivasi dan kinerja karyawan pada PT. Pentavalent Jambi berlangsung dengan tidak baik.

$\mathrm{H}_{1}$ : Kompensasi, komitmen organisasi, motivasi dan kinerja karyawan pada PT. Pentavalent Jambi berlangsung dengan baik.

2. Kompensasi secara parsial berpengaruh signifikan terhadap motivasi.

$\mathrm{H}_{0}$ : Kompensasi secara parsial berpengaruh signifikan terhadap motivasi.

$\mathrm{H}_{1}$ : Kompensasi secara parsial berpengaruh signifikan terhadap motivasi.

3. Komitmen organisasi secara parsial berpengaruh signifikan terhadap motivasi.

$\mathrm{H}_{0}$ : Komitmen organisasi secara parsial tidak berpengaruh signifikan terhadap motivasi.

$\mathrm{H}_{1}$ : Komitmen organisasi secara parsial berpengaruh signifikan terhadap motivasi.

4. Kompensasi dan komitmen organisasi secara simultan berpengaruh signifikan terhadap motivasi.

$\mathrm{H}_{0}$ : Kompensasi dan komitmen organisasi secara simultan tidak berpengaruh signifikan terhadap motivasi.

$\mathrm{H}_{1}$ : Kompensasi dan komitmen organisasi secara simultan berpengaruh signifikan terhadap motivasi.

5. Kompensasi secara parsial berpengaruh signifikan terhadap kinerja.

$\mathrm{H}_{0}$ : Kompensasi secara parsial berpengaruh signifikan terhadap kinerja.

$\mathrm{H}_{1}$ : Kompensasi secara parsial berpengaruh signifikan terhadap kinerja.

6. Komitmen organisasi secara parsial berpengaruh signifikan terhadap kinerja.

$\mathrm{H}_{0}$ : Komitmen organisasi secara parsial tidak berpengaruh signifikan terhadap kinerja.

$\mathrm{H}_{1}$ : Komitmen pegawai secara parsial berpengaruh signifikan terhadap kinerja.

7. Kompensasi dan Komitmen organisasi secara simultan berpengaruh signifikan terhadap kinerja.

$\mathrm{H}_{0}$ : Kompensasi dan Komitmen organisasi secara simultan tidak berpengaruh signifikan terhadap kinerja.

$\mathrm{H}_{1}$ : Kompensasi dan Komitmen organisasi secara simultan berpengaruh signifikan terhadap kinerja.

8. Motivasi secara parsial berpengaruh signifikan terhadap kinerja.

$\mathrm{H}_{0}$ : Motivasi secara parsial tidak berpengaruh signifikan terhadap kinerja. 
$\mathrm{H}_{1}$ : Motivasi secara parsial berpengaruh signifikan terhadap kinerja.

9. Kompensasi dan komitmen organisasi melalui motivasi berpengaruh signifikan terhadap kinerja.

$\mathrm{H}_{0}$ : Kompensasi dan komitmen organisasi melalui motivasi tidak berpengaruh signifikan terhadap kinerja.

$\mathrm{H}_{1}$ : Kompensasi dan komitmen organisasi melalui motivasi berpengaruh signifikan terhadap kinerja.

\section{Hasil}

\section{Pembahasan Hipotesis Pertama}

Hasil pengujian deskriptif untuk variabel kompensasi diperoleh skor ratarata sebesar 145,25; bahwasanya variabel kompensasi termasuk pada range 111,8 - 146,1 berada pada Kriteria Cukup Baik. Yang menjelaskan bahwasanya kompensasi yang diberikan oleh perusahaan kepada pegawai telah berlangsung cukup baik. Dimana skor tertinggi berada pada pernyataan ke tiga yaitu "Besaran gaji yang diterima telah sesuai dan sama dengan perusahaan lain" pada dimensi layak. Yang menjelaskan bahwa pada dasarnya karyawan telah merasa puas atas besaran gaji diterima. Karena gaji yang diberikan oleh PT. Penta Valent Jambi telah sesuai dan sama dengan perusahaan lain.

Sedangkan skor yang paling rendah berada pada pernyataan ke delapan "Adanya kesesuaian insentif yang diberikan dengan pekerjaan yang dilaksanakan" pada dimensi insentif. Temuan ini menunjukan hasil yang sama dengan pengamatan awal yang dilakukan yang menunjukan bahwa kompensasi berupa insentif yang diterima oleh karyawan dirasa belum begitu adil diberikan kepada karyawan. idak semua karyawan memperoleh insentif dari perusahaan. Hanya untuk kepala cabang, supervisor, salesman dan apoteker saja. Sedangkan untuk admin, pengantar barang dan bagian gudang tidak mendapatkan insentif dari perusahaan. Hal ini tentu saja membuat kecemburuan sosial dalam lingkungan perusahaan bagi mereka yang tidak mendapatkan insentif. Karena seharusnya semua karyawan berhak untuk mendapatkan insentif dari perusahaan, karena pada dasarnya semua karyawan sama-sama memberikan kontribusi untuk kemajuan perusahaan. Secara keseluruhan kompensasi yang diterima oleh karyawan pada PT. Penta Valent Jambi dikategorikan cukup baik, meskipun ada beberapa point yang mesti diperbaiki. Kompensasi adalah salah satu fungsi sumber daya manusia yang paling penting. Pemberian kompensasi tersebut merupakan salah satu faktor untuk beberapa aspek yang perlu diperhatikan dalam manajemen sumber daya manusia, seperti alasan mengapa seorang yang potensial mau bekerja pada suatu perusahaan dan salah satu faktor agar karyawan potensial akan loyal dan kontributif terhadap perusahaan. Kompensasi juga merupakan salah satu faktor mempengaruhi motivasi kerja dan kinerja karyawan yang ada pada perusahaan (Ivancevich dalam Verizqy, T dan Kusumastuti, R, 2014).

Hasil pengujian deskriptif untuk variabel komitmen organisasi diperoleh skor rata-rata sebesar 143,13; bahwasanya variabel komitmen oganisasi termasuk pada range 111,8 - 146,1 berada pada Kriteria Cukup Tinggi. Yang menjelaskan bahwasanya pegawai pada PT. Penta Valent Jambi memiliki komitmen yang cukup tinggi dalam bekerja pada organisasi tempat mereka bernaung. Dimana skor tertinggi berada pada pernyataan kedelapan pada dimensi kedua yakni "Dapat melaksanakan pekerjaan secara terus menerus". Hal ini mendiskripsikan bahwasanya pegawai pada PT. Penta Valent Jambi dapat melaksanakan pekerjaan yang diberikan secara terus menerus. Sedangkan untuk skor yang paling rendah 
berada pada pernyataan kedua dimensi pertama yakni "Adanya rasa senang menghabiskan karir dalam perusahaan ini". Dari hasil survey yang dilakukan pernyataan ini memiliki skor yang paling rendah dibandingkan dengan pernyataan lainnya. Hal ini menjelaskan bahwasanya pegawai belumlah begitu komitmen pada organisasi untuk dapat menghabiskan karirnya pada perusahaan ini, karena masih adanya keinginan pegawai untuk dapat pindah ke perusahaan lain yang menawarkan kesejahteraan yang lebih. Secara keseluruhan komitmen keorganisasian pegawai pada PT. Penta Valent Jambi dikategorikan cukup baik, meskipun ada beberapa point yang mesti diperbaiki. Komitmen terhadap organisasi artinya lebih dari sekedar keanggotaan formal, karena meliputi sikap menyukai organisasi dan kesediaan untuk mengusahakan tingkat upaya yang lebih tinggi bagi kepentingan organisasinya demi pencapaian tujuan. Allen dan Mayer dalam Sanusi (2012) menjelaskan bahwasanya komitmen organisasi merupakan suatu keadaan psikologi dengan karakteristik sebagai berikut: 1) meyakini dan menerima tujuan yang dimiliki oleh organisasi; 2) kesediaan untuk berusaha dengan sungguh-sungguh demi organisasi; 3) mempunyai keinginan yang kuat untuk tetap menjadi anggota organisasi.

Hasil pengujian deskriptif untuk variabel motivasi diperoleh skor rata-rata sebesar 148,06; bahwasanya variabel motivasi kerja termasuk pada range 111,8 146,1 berada pada Kriteria Cukup Tinggi. Yang menjelaskan bahwasanya pegawai pada PT. Penta Valent Jambi memiliki motivasi kerja yang tinggi dalam melaksanakan pekerjaannya.Dimana skor tertinggi berdasarkan hasil survey yang dilakukan berada pada pernyataan kesebelas yaitu "Adanya sikap saling menghargai antara satu dengan yang lainnya." yang menjelaskan bahwasanya hubungan kerja yang ada dengan sikap saling menghargai antara satu dengan yang lainnya dapat berlangsung dengan baik, sehingga mampu meningkatkan motivasi kerja pegawai dalam bekerja. Sedangkan untuk skor terendah berdasarkan hasil survey yang dilakukan berada pada pernyataan ketiga yaitu "Adanya penyediaan ruang kerja yang kondusif." Hal ini menjelaskan bahwasanya ruang kerja yang disediakan oleh perusahaan saat ini sebenarnya belumlah sesuai dengan harapan pegawai, sehingga membuat pegawai belum dapat bekerja secara optimal, yang berdampak terhadap kurangnya inisiatif pegawai dalam melaksanakan tugas pokok dan fungsinya. Secara keseluruhan motivasi kerja pegawai pada PT. Penta Valent Jambi dikategorikan cukup baik, meskipun ada beberapa point yang mesti diperbaiki. Motivasi yang merupakan faktor pendorong penting yang menyebabkan manusia bekerja, adalah adanya kebutuhan yang harus dipenuhi. Aktifitas dalam kerja mengandung unsur suatu kegiatan sosial, menghasilkan sesuatu, dan pada akhirnya bertujuan untuk memenuhi kebutuhannya. motivasi adalah pemberian daya penggerak yang menciptakan kegairahan seseorang, agar mau bekerja sama, bekerja efektif dan terintegrasi dengan segala daya upayanya untuk mencapai tujuan (Hasibuan, 2009).

Hasil pengujian deskriptif untuk variabel kinerja diperoleh nilai skor ratarata sebesar 149,11; bahwasanya variabel kinerja termasuk pada range 146,2 180,5 berada pada Kriteria Baik. Yang menjelaskan bahwasanya kinerja pegawai pada PT. Penta Valent Jambi sudah berlangsung dengan baik. Dimana skor tertinggi berada pada pernyataan pertama "Memiliki pengetahuan yang baik mengenai pedoman kerja sehari-hari". Hal ini mendiskripsikan bahwasanya pegawai pada PT. Penta Valent Jambi memiliki pengetahuan yang baik mengenai pedoman kerja sehari-hari, sehingga pegawai cukup mampu dalam melaksanakan tugas pokok dan fungsinya. Sedangkan untuk skor yang paling rendah berada 
pada pernyataan kesebelas "Dapat melaksanakan pekerjaan dengan mandiri tanpa harus menunggu perintah dari atasan". Hal ini menjelaskan bahwasanya sebagian pegawai belum begitu mampu bekerja secara mandiri berdasarkan inisiatif sendiri, melainkan harus menuggu perintah dari atasan. Keberhasilan suatu perusahaan sangat dipengaruhi oleh kinerja dari pegawainya, karena dengan kinerja yang baik tentu akan membawa hasil yang baik pula. Agar aktivitas kinerja dapat berjalan dengan baik, organisasi/instansi tentu harus memiliki pegawai yang berpengetahuan dan berketrampilan tinggi serta usaha untuk mengelola organisasi dengan optimal. Secara umum berdasarkan hasil survey yang dilakukan dengan penyebaran kuesioner kepada pegawai PT. Penta Valent Jambi telah berlangsung dengan baik, meskipun masih ada beberapa point yang harus dibenahi. Diharapkan kedepannya hasil kinerja yang baik ini dapat dipertahankan dan tingkatkan lagi guna untuk memberikan hasil kerja yang optimal dalam pencapaian visi dan misi instansi. Kinerja adalah penampilan yang melakukan, menggambarkan dan menghasilkan sesuatu hal, baik yang bersifat fisik dan non fisik yang sesuai dengan petunjuk, fungsi dan tugasnya yang didasari oleh pengetahuan, sikap, keterampilan, dan motivasi.

\section{Pembahasan Hipotesis Kedua Kompensasi Berpengaruh Terhadap Motivasi Kerja Secara Parsial.}

Untuk melakukan pengujian hipotesis kedua digunakan Uji Parsial (Uji-t) yang diolah dengan menggunakan Program SPSS versi 21.0, dimana untuk melihat pengaruh secara parsial antara kompensasi terhadap motivasi. Hasil pengujian yang dilakukan diperoleh angka nilai $\mathrm{t}$ hitung variabel $\mathrm{X}_{1}$ sebesar 2.708, dikarenakan nilai t hitung $>\mathrm{t}$ Tabel $(2.708>1.6829)$, maka secara parsial kompensasi memiliki pengaruh terhadap motivasi. Oleh karena itu maka $\mathrm{H}_{0}$ ditolak, artinya secara parsial terdapat pengaruh signifikan antara kompensasi dengan motivasi kerja pegawai. Selain itu pula untuk melakukan uji berdasarkan pengujian signifikansi, dapat dilihat dari output signifikansi sebesar 0,010, dikarenakan angka taraf signifikansi lebih $<0.05(0.010<0.05)$ maka dapat disimpulkan bahwa kompensasi berpengaruh terhadap motivasi kerja pegawai. Berdasarkan dari penjelasan tersebut oleh karena itu $\mathrm{H}_{0}$ ditolak dan $\mathrm{H}_{1}$ diterima, artinya kompensasi secara langsung dan tidak langsung berpengaruh terhadap motivasi kerja pegawai.

Besarnya pengaruh langsung kompensasi terhadap motivasi bernilai positif sebesar $13,18 \%$, begitu pula untuk pengaruh tidak langsung bernilai positif sebesar 9,49\% dan pengaruh total sebesar 22,67\%, hal ini menunjukan bahwa kompensasi secara langsung dan tidak langsung berpengaruh positif terhadap motivasi kerja pegawai, dimana pengaruh langsung memiliki nilai yang besar dibandingkan nilai pengaruh tidak langsung. Hal ini menjelaskan bahwasanya apabila kompensasi yang diberikan oleh perusahaan kepada pegawainya telah sesuai seperti yang diharapkan oleh pegawai, maka akan mampu meningkatkan motivasi kerja pegawai dalam bekerja. Hasil penelitian ini menunjukan hasil yang sama dengan penelitian yang dilakukan oleh Wulansari, P., Damanik, H.I., dan Prasetio, A.P (2014), Laminingrum, A.K (2016) dan Verizqy, T dan Kusumastuti, $\mathrm{R}$ (2014) yang menyatakan bahwa kompensasi memiliki pengaruh yang positif dan signifikan terhadap motivasi kerja. Secara Umum kompensasi merupakan balas jasa yang diterima oleh pegawai sehubungan dengan pengorbanan yang telah diberikan kepada organisasi. Tujuan pemberian kompensasi sendiri menurut Hasibuan (2008) adalah sebagai ikatan kerja sama, kepuasan kerja, pengadaan 
efektif, motivasi, stabilitas karyawan, disiplin, serta pengaruh serikat buruh dan pemerintah. Pemberian kompensasi ini bisa diberikan langsung berupa uang maupun tidak langsung berupa uang dari instansi kepada pegawainya. Kompensasi adalah keseluruhan balas jasa yang diterima oleh pegawai sebagai akibat dari pelaksanaan bekerja di organisasi dalam bentuk uang atau lainnya, yang dapat berupa gaji, upah, bonus insentif, dan tunjangan lainnya seperti tunjangan kesehatan, tunjangan hari raya, uang makan, uang cuti dan lain-lain (Hariandja, 2005:244).

\section{Pembahasan Hipotesis Ketiga Komitmen Organisasi Berpengaruh Terhadap Motivasi Kerja Secara Parsial.}

Untuk melakukan pengujian hipotesis ketiga berikutnya pengaruh komitmen organisasi terhadap motivasi digunakan Uji Parsial (Uji-t) yang diolah dengan menggunakan Program SPSS versi 21.0, dimana untuk melihat pengaruh secara parsial antara variabel komitmen organisasi terhadap variabel motivasi. Hasil pengujian yang dilakukan diperoleh angka nilai t hitung variabel $\mathrm{X}_{1}$ sebesar 3.366, dikarenakan nilai t hitung > t Tabel $(3.366>1.6829)$, maka secara parsial komitmen organisasi memiliki pengaruh terhadap motivasi kerja. Oleh karena itu maka $\mathrm{H}_{0}$ ditolak, artinya secara parsial terdapat pengaruh signifikan antara komitmen organisasi dengan motivasi. Selain itu pula untuk melakukan uji berdasarkan pengujian signifikansi, dapat dilihat dari output signifikansi sebesar 0,002 , dikarenakan angka taraf signifikansi $<0.05(0.002<0.05)$ maka dapat disimpulkan bahwa komitmen organisasi berpengaruh terhadap motivasi kerja. Berdasarkan dari penjelasan tersebut oleh karena itu $\mathrm{H}_{0}$ ditolak dan $\mathrm{H}_{1}$ diterima, artinya komitmen organisasi secara langsung dan tidak langsung berpengaruh terhadap motivasi kerja pegawai.

Besarnya pengaruh langsung komitmen organisasi terhadap motivasi bernilai positif sebesar 20,34\%, begitu pula untuk pengaruh tidak langsung bernilai positif sebesar $9,49 \%$ dan pengaruh total sebesar $29,83 \%$, hal ini menunjukan bahwa komitmen organisasi secara langsung dan tidak langsung berpengaruh positif terhadap motivasi, dimana pengaruh langsung memiliki nilai yang besar dibandingkan nilai tidak langsung. Hal ini menjelaskan bahwasanya apabila pegawai memiliki komitmen yang tinggi terhadap organisasinya, maka dengan sendirinya pegawai tersebut akan mampu meningkatkan motivasi kerja dalam melaksanakan tugas. Beberapa penelitian juga telah membuktikan jika komitmen organisasi memiliki pengaruh terhadap motivasi kerja, diantaranya yaitu penelitian yang dilakukan oleh Farida, S.I., Iqbal, M., dan Kurniasih, A (2016), Tranggono, R.P., dan Kartika, A (2008), dan Arifah, D.A., dan Romadhon, C (2015) yang menyatakan bahwa komitmen organisasi memiliki pengaruh yang positif dan signifikan terhadap motivasi kerja. Komitmen organisasi merupakan identifikasi dan keterlibatan seseorang yang relatif kuat terhadap organisasi. Komitmen organisasional adalah keinginan anggota organisasi untuk tetap mempertahankan keanggotaannya dalam organisasi dan bersedia berusaha keras bagi pencapaian tujuan organisasi (Sopiah, 2008). Dalam manajemen organisasi diperlukan hubungan yang lebih baik dan keinginan para karyawan yaitu saling mencintai para karyawan yang mau bekerja dan mempunyai komitmen organisasi yang tinggi. 


\section{Pembahasan Hipotesis Keempat Kompensasi dan Komitmen Organisasi} Terhadap Motivasi Kerja Secara Simultan.

Uji Anova atau $\mathrm{F}$ test dengan menggunakan SPSS 21.0 didapat $\mathrm{F}_{\text {hitung }}$ sebesar 22.037 dengan tingkat probabilitas p-value sebesar 0,000, dikarenakan nilai $\mathrm{F}_{\text {hitung }}>\mathrm{F}_{\text {tabel }}(22.037>3.23)$ sehingga dapat disimpulkan bahwa hipotesis nol $\left(\mathrm{H}_{0}\right)$ ditolak dan Hipotesa alternatif $\left(\mathrm{H}_{1}\right)$ diterima, artinya ada pengaruh signifikan antara kompensasi dan komitmen organisasi secara bersama-sama terhadap motivasi kerja. Jadi pada penelitian ini dapat disimpulkan bahwa kompensasi dan komitmen organisasi secara simultan berpengaruh terhadap motivasi kerja pegawai pada PT. Penta Valent Jambi. Selain itu pula untuk melakukan uji berdasarkan pengujian signifikansi, dapat dilihat dari output signifikansi sebesar 0,000, dikarenakan angka taraf signifikansi jauh lebih $<0.05$ $(0.000<0.05)$ oleh karena itu berdasarkan penjelasan tersebut maka $\mathrm{H}_{0}$ ditolak dan $\mathrm{H}_{1}$ diterima, artinya hal ini membuktikan bahwa variabel kompensasi dan komitmen organisasi secara bersama-sama berpengaruh secara signifikan terhadap variabel motivasi kerja.

Selain itu pula perhitungan nilai total pengaruh langsung dan tidak langsung kompensasi dan komitmen organisasi secara bersama-sama terhadap motivasi sebesar 52.4\%, dimana angka tersebut menjelaskan bahwa secara langsung kompensasi dan komitmen organisasi memberikan kontribusi terhadap motivasi kerja sebesar 52.4\%. Dimana Nilai total pengaruh $\mathrm{X}_{1}, \mathrm{X}_{2}$ tersebut menjelaskan nilai koefisien determinasi $R^{2}$, dimana nilai $R$ sebesar 0,724 menunjukan korelasi ganda (kompensasi dan komitmen organisasi) dengan motivasi. Dengan mempertimbangkan variasi Nilai $R$ Square sebesar 0,500 yang menunjukan besarnya peran atau kontribusi variabel kompensasi dan komitmen organisasi mampu menjelaskan variabel motivasi sebesar 50\% dan sisanya 50\% dipengaruhi oleh variabel lain yang tidak termasuk dalam model ini.

\section{Pembahasan Hipotesis Kelima Kompensasi Berpengaruh Terhadap Kinerja.}

Untuk melakukan pengujian hipotesis kelima digunakan Uji Parsial (Uji-t) yang diolah dengan menggunakan Program SPSS versi 21.0, dimana untuk melihat pengaruh secara parsial antara variabel kompensasi terhadap variabel kinerja. Dari hasil pengujian yang dilakukan diperoleh nilai t-hitung variabel $\mathrm{X}_{1}$ sebesar 3.538, dikarenakan nilai t hitung > t Tabel $(3.538>1.6829)$, maka secara parsial kompensasi memiliki pengaruh terhadap kinerja pegawai. Oleh karena itu maka $\mathrm{H}_{0}$ ditolak, artinya secara parsial terdapat pengaruh signifikan antara kompensasi dengan kinerja pegawai. Selain itu pula untuk melakukan uji berdasarkan pengujian signifikansi, dapat dilihat dari output signifikansi sebesar 0,001, dikarenakan angka taraf signifikansi lebih $<0.05(0.001<0.05)$ maka dapat disimpulkan bahwa kompensasi berpengaruh terhadap kinerja pegawai. Berdasarkan dari penjelasan tersebut oleh karena itu $\mathrm{H}_{0}$ ditolak dan $\mathrm{H}_{1}$ diterima, artinya kompensasi secara langsung dan tidak langsung berpengaruh terhadap kinerja pegawai.

Besarnya pengaruh langsung kompensasi terhadap kinerja bernilai positif sebesar $18,15 \%$, begitu pula untuk pengaruh tidak langsung bernilai positif sebesar $10,84 \%$ dan pengaruh total sebesar $28,99 \%$, hal ini menunjukan bahwa kompensasi secara langsung dan tidak langsung berpengaruh positif terhadap kinerja pegawai, dimana pengaruh langsung memiliki nilai yang besar dibandingkan nilai pengaruh tidak langsung. Hal ini menjelaskan bahwasanya apabila kompensasi yang diterima oleh pegawai sudah sesuai dengan harapan 
pegawai, maka pegawaipun akan mampu memberikan hasil kerja yang optimal untuk organisasi. Hasil penelitian ini menunjukan hasil yang sama dengan penelitian yang dilakukan oleh Hakim dan Widyatmini (2008), Dermawan, Sudibya dan Utama (2012) dan Sarah Sasmita (2009) yang menyatakan bahwa kompensasi memiliki pengaruh yang positif dan signifikan terhadap kinerja. Hal ini menjelaskan bahwasanya jika kompensasi yang diterima oleh karyawan telah sesuai dengan kontribusi yang diberikan oleh karyawan kepada perusahaan, maka dengan senantiasa karyawa akan mampu meningkatkan kinerjanya dengan memberikan kualitas dan kuantitas kerjanya untuk mencapai tujuan perusahaan.

Secara keseluruhan kompensasi yang diterima oleh karyawan pada PT. Penta Valent Jambi dikategorikan cukup baik, meskipun ada beberapa point yang mesti diperbaiki. Kompensasi adalah salah satu fungsi sumber daya manusia yang paling penting. Pemberian kompensasi tersebut merupakan salah satu faktor untuk beberapa aspek yang perlu diperhatikan dalam manajemen sumber daya manusia, seperti alasan mengapa seorang yang potensial mau bekerja pada suatu perusahaan dan salah satu faktor agar karyawan potensial akan loyal dan kontributif terhadap perusahaan. Kompensasi juga merupakan salah satu faktor mempengaruhi motivasi kerja dan kinerja karyawan yang ada pada perusahaan (Ivancevich dalam Verizqy, T dan Kusumastuti, R, 2014).

Secara Umum kompensasi merupakan balas jasa yang diterima oleh pegawai sehubungan dengan pengorbanan yang telah diberikan kepada instansi. Tujuan pemberian kompensasi sendiri menurut Hasibuan (2008:121-122) adalah sebagai ikatan kerja sama, kepuasan kerja, pengadaan efektif, motivasi, stabilitas karyawan, disiplin, serta pengaruh serikat buruh dan pemerintah. Pemberian kompensasi ini bisa diberikan langsung berupa uang maupun tidak langsung berupa uang dari perusahaan kepada pegawainya.

Pada dasarnya kompensasi bertujuan untuk memberikan balas jasa kepada pegawai atas apa yang telah mereka berikan untuk organisasi antara lain adalah sebagai ikatan kerja sama, kepuasan kerja, pengadaan efektif, motivasi, stabilitas karyawan, disiplin, serta pengaruh serikat buruh dan pemerintah (Hasibuan, 2008:121-122). Asas Kompensasi Manajemen Program kompensasi (balas jasa) harus ditetapkan atas asas adil dan layak serta dengan memperhatikan UndangUndang perburuhan yang berlaku. Prinsip adil dan layak harus mendapat perhatian dengan sebaik-baiknya supaya balas jasa yang akan diberikan merangsang gairah dan kepuasan kerja pegawai.

\section{Pembahasan Hipotesis Keenam Komitmen Organisasi Berpengaruh Terhadap Kinerja.}

Untuk melakukan pengujian hipotesis keenam berikutnya pengaruh komitmen organisasi terhadap kinerja digunakan Uji Parsial (Uji-t) yang diolah dengan menggunakan Program SPSS versi 21.0, dimana untuk melihat pengaruh secara parsial antara variabel komitmen organisasi terhadap variabel kinerja. Hasil pengujian yang dilakukan diperoleh nilai t-hitung variabel $\mathrm{X}_{2}$ sebesar 3.538, dikarenakan nilai $\mathrm{t}$ hitung $>\mathrm{t}$ Tabel $(3.538>1.6829)$, maka secara parsial komitmen organisasi memiliki pengaruh terhadap kinerja pegawai. Oleh karena itu maka $\mathrm{H}_{0}$ ditolak, artinya secara parsial terdapat pengaruh signifikan antara komitmen organisasi dengan kinerja pegawai. Selain itu pula untuk melakukan uji berdasarkan pengujian signifikansi, dapat dilihat dari output signifikansi sebesar 0,001, dikarenakan angka taraf signifikansi lebih $<0.05(0.001<0.05)$ maka dapat disimpulkan bahwa komitmen organisasi berpengaruh terhadap 
kinerja pegawai. Berdasarkan dari penjelasan tersebut oleh karena itu $\mathrm{H}_{0}$ ditolak dan $\mathrm{H}_{1}$ diterima, artinya komitmen organisasi secara langsung dan tidak langsung berpengaruh terhadap kinerja pegawai.

Besarnya pengaruh langsung komitmen organisasi terhadap kinerja bernilai positif sebesar 19,27\%, begitu pula untuk pengaruh tidak langsung bernilai positif sebesar $10,85 \%$ dan pengaruh total sebesar $30,12 \%$, hal ini menunjukan bahwa komitmen organisasi secara langsung dan tidak langsung berpengaruh positif terhadap kinerja pegawai, dimana pengaruh langsung memiliki nilai yang besar dibandingkan nilai pengaruh tidak langsung. Hal ini menjelaskan bahwasanya apabila pegawai memiliki komitmen yang tinggi terhadap organisasi, maka pegawai tersebut akan mampu memberikan hasil kerja yang optimal.

Beberapa penelitian yang telah dilakukan sebelumnya juga telah membuktikan jika komitmen organisasi memiliki pengaruh terhadap kinerja pegawai, diantaranya yakni penelitian yang dilakukan oleh Supriyani dan Mahmud (2013), Abrivianto, Swasto dan Utami (2014) dan Suwardi dan Utomo (2011) yang menyatakan secara signifikan dan positif kinerja dipengaruhi oleh komitmen organisasi. Artinya apabila pegawai memiliki komitmen yang tinggi terhadap organisasi tempat mereka bernaung, maka dengan senantiasa pegawai tersebut akan mampu memberikan hasil kerja yang optimal. Pegawai yang memiliki komitmen yang tinggi adalah mereka yang merasa terpaut dengan organisasi tempat mereka bekerja dan melibatkan diri secara aktif di dalam pekerjaan yang menjadi bidang tanggung jawab mereka. Dengan kata lain, pegawai yang memiliki komitmen tinggi adalah mereka yang mengenali dan mencintai organisasi mereka dan terlibat aktif dalam memenuhi tugas dengan memberikan hasil kerja yang maksimal dalam pencapaian tujuan organisasi.

Secara keseluruhan komitmen keorganisasian pegawai pada PT. Penta Valent Jambi dikategorikan cukup baik, meskipun ada beberapa point yang mesti diperbaiki. Komitmen organisasi merupakan suatu keadaan dimana seseorang pegawai memihak organisasi tertentu serta tujuan dan keinginannya untuk mempertahankan keanggotaan dalam organisasi tersebut. Komitmen terhadap organisasi artinya lebih dari sekedar keanggotaan formal, karena meliputi sikap menyukai organisasi dan kesediaan untuk mengusahakan tingkat upaya yang lebih tinggi bagi kepentingan organisasinya demi pencapaian tujuan.

\section{Pembahasan Hipotesis Ketujuh Kompensasi dan Komitmen Organisasi Terhadap Kinerja.}

Pada pengujian hipotesis ini (ketujuh) akan diuji sesuai dengan paradigma yang mencerminkan hipotesis yaitu kompensasi dan komitmen organisasi secara bersama-sama berpengaruh terhadap kinerja karyawan pada PT. Penta Valent Jambi. Uji Anova atau F test dengan menggunakan SPSS 21.0 didapat $F_{\text {hitung }}$ sebesar 28.891 dengan tingkat probabilitas p-value sebesar 0,000, dikarenakan nilai $F_{\text {hitung }}>F_{\text {tabel }}(28.891>3.23)$ sehingga dapat disimpulkan bahwa hipotesis nol $\left(\mathrm{H}_{0}\right)$ ditolak dan Hipotesa alternatif $\left(\mathrm{H}_{1}\right)$ diterima, artinya ada pengaruh signifikan antara kompensasi dan komitmen organisasi secara bersama-sama terhadap kinerja karyawan. Jadi pada penelitian ini dapat disimpulkan bahwa kompensasi dan komitmen organisasi secara simultan berpengaruh terhadap kinerja karyawan pada PT. Penta Valent Jambi. Selain itu pula untuk melakukan uji berdasarkan pengujian signifikansi, dapat dilihat dari output signifikansi sebesar 0,000, dikarenakan angka taraf signifikansi jauh lebih $<0.05(0.000<$ 
0.05) oleh karena itu berdasarkan penjelasan tersebut maka $\mathrm{H}_{0}$ ditolak dan $\mathrm{H}_{1}$ diterima, artinya hal ini membuktikan bahwa variabel kompensasi dan komitmen organisasi secara bersama-sama berpengaruh secara signifikan terhadap variabel kinerja $(Z)$.

Selain itu pula perhitungan nilai total pengaruh langsung dan tidak langsung kompensasi dan komitmen organisasi secara bersama-sama terhadap kinerja pegawai sebesar $59.12 \%$, dimana angka tersebut menjelaskan bahwa secara langsung kompensasi dan komitmen organisasi memberikan kontribusi terhadap kinerja karyawan sebesar $59.12 \%$. Dimana Nilai total pengaruh $X_{1}, X_{2}$ tersebut menjelaskan nilai koefisien determinasi $\mathrm{R}^{2}$, dimana nilai $\mathrm{R}$ sebesar 0,769 menunjukan korelasi ganda (kompensasi dan komitmen organisasi) dengan kinerja karyawan. Dengan mempertimbangkan nilai variasi $\mathrm{R}$ Square sebesar 0,570 yang menunjukan besarnya peran atau kontribusi variabel kompensasi dan komitmen organisasi mampu menjelaskan variabel kinerja sebesar 57\% dan sisanya $43 \%$ dipengaruhi oleh variabel lain yang tidak termasuk dalam model ini.

\section{Pembahasan Hipotesis Kedelapan Motivasi Berpengaruh Terhadap Kinerja.}

Dalam pengujian hipotesis kedelapan digunakan Uji Parsial (Uji-t) yang diolah dengan menggunakan Program SPSS versi 21.0, dimana untuk melihat pengaruh secara parsial antara variabel motivasi terhadap variabel kinerja. Dari hasil pengujian yang dilakukan pada Tabel 4.17 diperoleh nilai t-hitung variabel motivasi belajar sebesar 5.984, dikarenakan nilai t hitung > t Tabel (5.984 > 1.6829), maka secara parsial motivasi memiliki pengaruh terhadap kinerja pegawai. Oleh karena itu maka $\mathrm{H}_{0}$ ditolak, artinya secara parsial terdapat pengaruh signifikan antara motivasi dengan kinerja pegawai. Selain itu pula untuk melakukan uji berdasarkan pengujian signifikansi, dapat dilihat dari output signifikansi sebesar 0,000, dikarenakan angka taraf signifikansi lebih $<0.05$ $(0.000<0.05)$ maka dapat disimpulkan bahwa motivasi berpengaruh terhadap kinerja karyawan. Berdasarkan dari penjelasan tersebut oleh karena itu $\mathrm{H}_{0}$ ditolak dan $\mathrm{H}_{1}$ diterima, artinya motivasi secara langsung berpengaruh terhadap kinerja karyawan.

Besarnya pengaruh pengaruh langsung motivasi terhadap kinerja 46,65\%, ini menunjukan bahwa motivasi secara langsung berpengaruh terhadap kinerja pegawai pada PT. Penta Valent Jambi. Hal ini menjelaskan bahwasanya apabila pegawai memiliki motivasi kerja yang tinggi dalam melaksanakan tugas pokok dan fungsinya, maka pegawai tersebut akan mampu memberikan kontribusi kerja yang baik pula dalam upaya mencapai target perusahaan. Hasil penelitian ini dapat mendukung penelitian McClelland (1961), Edward Murray (1957), Miller dan Gordon W (1970), Mangkunegara (2000) menyimpulkan bahwa adanya hubungan yang positif antara motivasi dengan pencapaian kinerja. Artinya, pimpinan, manajer dan pegawai yang mempunyai motivasi yang tinggi akan dapat mencapai kinerja yang tinggi pula, dan sebaliknya mereka yang kinerjanya rendah disebabkan karena motivasi kerjanya rendah (Mangkunegara, 2014:76).

Selain itu pula hasil penelitian ini juga menunjukan hasil yang sama dengan penelitian yang dilakukan oleh Dermawan, Sudibya dan Utama (2012), Supriyani dan Mahmud (2013), Suwardi dan Utomo (2011) dan Abrivianto, Swasto dan Utami (2014) yang mengungkapkan bahwasanya kinerja pegawai juga dipengaruhi oleh motivasi. Motivasi adalah suatu faktor yang mendorong seseorang untuk melakukan suatu aktivitas tertentu, oleh karena itu motivasi 
sering kali diartikan pula sebagai faktor pendorong perilaku seseorang (Sutrisno, 2010).

Secara keseluruhan motivasi kerja pegawai pada PT. Penta Valent Jambi dikategorikan cukup baik, meskipun ada beberapa point yang mesti diperbaiki. Motivasi yang merupakan faktor pendorong penting yang menyebabkan manusia bekerja, adalah adanya kebutuhan yang harus dipenuhi. Aktifitas dalam kerja mengandung unsur suatu kegiatan sosial, menghasilkan sesuatu, dan pada akhirnya bertujuan untuk memenuhi kebutuhannya. motivasi adalah pemberian daya penggerak yang menciptakan kegairahan seseorang, agar mau bekerja sama, bekerja efektif dan terintegrasi dengan segala daya upayanya untuk mencapai tujuan (Hasibuan, 2009).

Motivasi merupakan dorongan dari dalam diri pegawai untuk mencapai suatu tujuan. Seorang karyawan akan melakukan tugasnya dengan baik jika ada dorongan dari dalam dirinya. Dorongan itu akan timbul jika seseorang mempunyai kebutuhan untuk dipenuhinya. Menurut Maslow dalam Triatna (2015:86) kebutuhan seseorang tersebut terentang dari kebutuhan yang paling bawah sampai kebutuhan yang paling tinggi. Maslow mengemukakan lima hierarki kebutuhan bagi manusia yaitu kebutuhan dasar, keamanan, social, penghargaan, dan aktualisasi.

Maslow dalam Mangkunegara (2011) mengatakan bahwa motivasi merupakan Kondisi jiwa yang mendorong seseorang dalam mencapai prestasinya secara maksimal. Motivasi merupakan faktor yang mempengaruhi semangat dan kegairahan kerja pegawai untuk berperan serta secara aktif dalam proses kerja sehingga akan mampu memberikan hasil kerja yang lebih optimal. Menurut Herzberg dalam Hasibuan (2009), ada dua jenis faktor yang mendorong seseorang untuk berusaha mencapai kepuasan dan menjauhkan diri dari ketidakpuasan. Dua faktor itu disebutnya faktor higiene (faktor ekstrinsik) dan faktor motivator (faktor intrinsik).

\section{Pembahasan Hipotesis Kesembilan Kompensasi dan Komitmen Organisasi Melalui Motivasi Terhadap Kinerja.}

Proses perhitungan analisis jalur yang dilakukan dapat disimpulkan bahwa kompensasi terhadap kinerja melalui motivasi pengaruhnya sebesar 10,56\%, dan pegaruh kompensasi terhadap kinerja melalui komitmen organisasi dan motivasi sebesar $7,61 \%$ dan total pengaruhnya adalah sebesar $18,17 \%$ dimana angka tersebut menjelaskan bahwa kompensasi melalui motivasi memberikan sumbangan terhadap kinerja pegawai pada PT. Penta Valent Jambi.

Sedangkan komitmen organisasi terhadap kinerja pegawai melalui motivasi kerja pengaruhnya sebesar $13,52 \%$, dan pegaruh komitmen organisasi terhadap kinerja melalui kompensasi sebesar 6,31\% dan total pengaruhnya adalah sebesar 19,83\% dimana angka tersebut menjelaskan bahwa komitmen organisasi melalui motivasi memberikan sumbangan terhadap kinerja pegawai pada PT. Penta Valent Jambi.

Kemudian pengaruh langsung kompensasi dan komitmen organisasi secara bersama-sama melalui motivasi terhadap kinerja pegawai adalah sebesar $24,08 \%$, pengaruh tidak langsungnya adalah sebesar $13,92 \%$ dan total pengaruhnya adalah sebesar 38\%. Dengan demikian, secara bersama-sama variabel kompensasi dan komitmen organisasi melalui motivasi memberikan sumbangan terhadap kinerja pegawai pada PT. Penta Valent Jambi. Motivasi sebagai proses yang ikut menentukan intensitas, arah, dan ketekunan individu dalam usaha mencapai 
sasaran. Motivasi sebagai pemberian motif, penimbulan motif atau hal yang menimbulkan dorongan atau keadaan yang menimbulkan dorongan. Setiap individu memerlukan motivasi dalam bekerja. Adanya motivasi akan menimbulkan semangat kerja karena motivasi merupakan suatu dorongan dalam diri seseorang untuk melakukan sesuatu. Dengan kebutuhan yang berbeda-beda maka setiap perilaku individu dalam mencapai tujuan akan berbeda motivasinya (Robbins, 2007:213). Hasil penelitian menunjukkan bahwa pemberikan kompensasi yang sesuai diberikan kepada karyawan serta di dukung komitmen kerja yang tinggi dimiliki oleh karyawan dalam melaksanakan pekerjaannya akan mampu meningkatkan motivasi kerja karyawan. Bentuk motivasi kerja yang dirasakan karyawan akan diimplementasikan dengan memberikan hasil kerja yang optimal.

\section{SIMPULAN}

Penelitian ini membuat beberapa kesimpulan berdasarkan hasil penelitian, yaitu:

1. Kompensasi secara parsial berpengaruh positif dan signifikan terhadap motivasi kerja karaywan pada PT. Penta Valent Jambi. Dimana pengaruh langsung kompensasi terhadap motivasi bernilai positif sebesar $13,18 \%$, begitu pula untuk pengaruh tidak langsung bernilai positif sebesar 9,49\% dan pengaruh total sebesar $22,67 \%$

2. Komitmen organisasi secara parsial berpengaruh positif dan signifikan terhadap motivasi kerja pegawai pada PT. Penta Valent Jambi. Dimana pengaruh langsung komitmen organisasi terhadap motivasi bernilai positif sebesar 20,34\%, begitu pula untuk pengaruh tidak langsung bernilai positif sebesar 9,49\% dan pengaruh total sebesar $29,83 \%$.

3. Kompensasi dan komitmen organisasi secara simultan berpengaruh positif dan signifikan terhadap motivasi kerja pegawai pada PT. Penta Valent Jambi. Dimana total pengaruh langsung dan tidak langsung kompensasi dan komitmen organisasi secara bersama-sama terhadap motivasi sebesar 52,4\%, dimana angka tersebut menjelaskan bahwa secara langsung kompensasi dan komitmen organisasi memberikan kontribusi terhadap motivasi kerja sebesar $52.4 \%$, sedangkan sisanya sebesar $47,6 \%$ dipengaruhi oleh variabel lain yang tidak termasuk dalam model ini.

4. Kompensasi secara parsial berpengaruh positif dan signifikan terhadap kinerja karyawan pada PT. Penta Valent Jambi. Dimana pengaruh langsung kompensasi terhadap kinerja bernilai positif sebesar $18,15 \%$, begitu pula untuk pengaruh tidak langsung bernilai positif sebesar $10,84 \%$ dan pengaruh total sebesar 28,99\%.

5. Komitmen organisasi secara parsial berpengaruh positif dan signifikan terhadap kinerja pegawai pada PT. Penta Valent Jambi. Dimana pengaruh langsung komitmen organisasi terhadap kinerja bernilai positif sebesar $19,27 \%$, begitu pula untuk pengaruh tidak langsung bernilai positif sebesar $10,85 \%$ dan pengaruh total sebesar $30,12 \%$.

6. Kompensasi dan komitmen organisasi secara simultan berpengaruh positif dan signifikan terhadap kinerja pegawai pada PT. Penta Valent Jambi. Dimana total pengaruh langsung dan tidak langsung kompensasi dan komitmen organisasi secara bersama-sama terhadap kinerja pegawai sebesar $59.12 \%$, dimana angka tersebut menjelaskan bahwa secara langsung kompensasi dan komitmen organisasi memberikan kontribusi terhadap 
kinerja karyawan sebesar 59.12\%, sedangkan sisanya sebesar 40,9\% dipengaruhi oleh variabel lain yang tidak termasuk dalam model ini.

7. Motivasi kerja secara parsial berpengaruh positif dan signifikan terhadap kinerja karyawan pada PT. Penta Valent Jambi. Dimana pengaruh langsung motivasi terhadap kinerja bernilai positif sebesar 46,65\%.

8. Kompensasi dan komitmen organisasi secara bersama-sama melalui motivasi dapat berpengaruh langsung dan tidak langsung terhadap terhadap kinerja karyawan pada PT. Penta Valent Jambi. Dimana pengaruh kompensasi terhadap kinerja melalui motivasi pengaruhnya sebesar $10,56 \%$, pengaruh komitmen organisasi terhadap kinerja pegawai melalui motivasi kerja pengaruhnya sebesar $13,52 \%$, dan pengaruh kompensasi dan komitmen organisasi secara bersama-sama melalui motivasi terhadap kinerja pegawai adalah sebesar $24,08 \%$.

\section{DAFTAR PUSTAKA}

Abrivianto, O.P., Swasto, B dan Utami, H.N. (2014). Pengaruh Motivasi Kerja dan Komitmen Organisasional Terhadap Kinerja Karyawan (Studi pada karyawan bagian HRD PT. Arthawena Sakti Gemilang Malang). Jurnal Administrasi Bisnis (JAB). Vol. 7 No. 2.

Arifah, D.A., dan Romadhon, C. (2015). Pengaruh Komitmen Organisasi, Komitmen Profesional dan Gaya Kepemimpinan Terhadap Kepuasan Kerja Dengan Motivasi Sebagai Variabel Intervening. Journal Conference in Business Accounting, and Management, Vol. 2, No. 1.

Arikunto, S. (2007). Prosedur Penelitian Suatu Pendekatan Praktek, Edisi Revisi, Jakarta: Rineka Cipta.

Azwar, S. (2007). Reliabilitas dan Validitas. Yogyakarta: Pustaka Pelajar

Darmawan, D. (2013). Prinsip-Prinsip Perilaku Organisasi. Surabaya: Temprina Media Grafika.

Dermawan, Sudibya dan Utama. (2012). Pengaruh Motivasi, Lingkungan Kerja, Kompetensi, dan Kompensasi terhadap Kepuasan kerja dan Kinerja Pegawai Di Lingkungan Kantor Dinas Pekerjaan Umum Provinsi Bali. Jurnal Manajemen Strategi Bisnis dan Kewirausahaan Vol. 6 No. 2.

Farida, S.I., Iqbal, M., dan Kurniasih, A. (2016). Pengaruh Kepercayaan dan Komitmen Organisasi Terhadap Motivasi dan Kepuasan Kerja. Jurnal Universitas Mercu Buana.

Ghozali, I. (2011). Aplikasi Analisis Multivariate Dengan Program SPSS. Semarang: UNDIP

Hakim dan Widyatmini. (2008). Hubungan Kepemimpinan, Kompensasi dan Kompetensi Terhadap Kinerja Pegawai Dinas Kesehatan Kota Depok. Jurnal Ekonomi Bisnis No. 2 Vol. 13.

Hariandja, M. T. E. (2007), Manajemen Sumber Daya Manusia. Jakarta: PT. Grasindo.

Hasibuan, M. S. P., (2010), Manajemen Sumber Daya Manusia, edisi Revisi, Jakarta: Bumi Aksara.

Indriantoro, N. \& Supomo, B. (2007). Metodologi Penelitian. Jakarta: Indeks. Kinicki \& Kreitner.(2010). Organizational Behavior. New York: Mc Graw Hill. Kuncoro, M. (2008). Metode Riset Untuk Bisnis dan Ekonomi Bagaimana Meneliti dan Menulis Tesis, Edisi 3. Jakarta: Erlangga. 
Laminingrum, A.K. (2016). Pengaruh Kompensasi Terhadap Motivasi Kerja Pada Karyawan Biro Pelayanan Sosial Dasar di Sekretariat Daerah Provinsi Jawa Barat. Jurnal Administrasi Publik, Universitas Telkom.

Luthans,F.(2006) Perilaku Organisasi, Yogyakarta: Andi.

Mangkunegara, A. P. (2014), Evaluasi Kinerja Sumber Daya Manusia, edisi pertama, cetakan pertama. Bandung : Refika Aditama.

Martoyo, S. (2009). Manajemen Sumber Daya Manusia, Edisi 5, Cetakan Pertama. Yogyakarta: BPFE.

Mathis, R. L \& Jackson, J. H. (2007). Manajemen Sumber Daya Manusia, Jilid 3, Jakarta: Salemba Empat.

Nawawi, H. (2007). Manajemen Sumber Daya Manusia, Cetakan kelima. Yogyakarta: Gajah Mada University Press.

Rivai, V dan Sagala, E.J. (2009). Manjemen Sumber Daya Manusia Untuk Perusahaan Dari Teori Ke Praktik. Jakarta: RajaGrafindo.

Robbins, S.P and Judge, T.A. (2013). Organizational Behavior. New Jersey: Pearson Education, Inc.

Sasmita, S. (2009). Pengaruh Kompensasi Langsung dan Kompensasi tidak Langsung terhadap Semangat Kerja Karyawan PT. Sinar Sosro Medan. Tesis. Medan : Universitas Sumatra Utara, Program Pascasarjana.

Sastrohadiwiryo, B. S. (2007). Manajemen Tenaga Kerja Indonesia Pendekatan Administrasi dan Operasional. Jakarta: Bumi Aksara.

Sedarmayanti. (2009). Sumber Daya Manusia dan Produktivitas Kerja. Bandung: Mandar Maju.

Simamora, H. (2006). Manajemen Sumber Daya Manusia, edisi keempat, cetakan pertama. Yogyakarta: YKPN.

Sopiah.(2008). Perilaku Organisasional. Yogyakarta: Andi.

Sugiyono. (2010). Metode Penelitian Bisnis. Bandung: Alfabet

Supangat, A. (2007). Statistika Dalam Kajian Deskriptif, Inferensi, dan Nonparametrik. Edisi Pertama. Jakarta: Kencana.

Supriyani dan Mahmud. (2013). Membangun Kinerja Karyawan Melalui Motivasi Kerja, Kepuasan Kerja dan Komitmen Organisasi Pada PT. Astra International di Semarang.

Sutrisno, E. (2012). Manajemen Sumber Daya Manusia. Jakarta: Kencana.

Suwardi dan Utomo, J. (2011). Pengaruh Motivasi Kerja, Kepuasan Kerja dan Komitmen Organisasional Terhadap Kinerja Pegawai (Studi Pada Pegawai Setda Kabuapten Pati). Analisis Manajemen. Vol. 5, No. 1.

Suwatno. (2011). Manajemen SDM dalam Organisasi Publik dan Bisnis. Bandung: Alfabeta.

Tranggono, R.P., dan Kartika, A. (2008). Pengaruh Komitmen Organisasional dan Profesional Terhadap Kepuasan Kerja Auditor Dengan Motivasi Sebagai Variabel Intervening (Studi Empiris pada Kantor Akuntan Publik di Semarang). Jurnal Bisnis dan Ekonomi (JBE), Vol. 15, No. 1.

Triatna, C.(2015). Perilaku Organisasi dalam Pendidikan. Bandung: Remaja Rosdakarya Offset.

Umar, H. (2008). Metode Riset Bisnis: Dilengkapi Contoh Proposal dan Riset Bidang Manajemen dan Akuntansi. Jakarta: Gramedia Pustaka Utama.

Verizqy, T., dan Kusumastuti (2014). Pengaruh Kompensasi Terhadap Motivasi Kerja Pegawai Tetap Direktorat Sumber Daya Manusia di Kantor Pusat PT. Pertamina (Persero). Jurnal Ilmu Administrasi Niaga Universitas Indonesia. 
Wahyudi, B. (2007). Manajemen Sumber Daya Manusia, Bandung: Sulita.

Wibowo.( 2010). Manajemen Kinerja. Jakarta: RajaGrafindo.

Wukir. (2013). Manajemen Sumber daya Manusia dalam Organisasi sekolah. Yogyakarta: Multi Presindo.

Wulansari, P., Damanik, A.H., dan Prasetio, A.P. (2014). Pengaruh Kompesnsasi Terhadap Motivasi Karyawan di Departemen Sumberdaya Manusia PLN Kantor Distribusi Jawa Barat dan Banten. Jurnal Manajemen Indonesia, Vol. 14. No. 2.

Yuniarsih, T dan Suwatno. (2008). Manajemen Sumber Daya Manusia. Bandung: Alfa Beta. 